\title{
Characterization of Indoor/Outdoor Settled Dust and Air Pollutants in Damaturu, Nigeria
}

\author{
Fatima S. Mohammed and Derrick Crump
}

\begin{abstract}
This paper presents results of on-going experiments being undertaken to characterise the composition of settled dusts and some airborne contaminantsin homes and outdoors in Damaturu, north-eastern Nigeria. These have involved the physical analysis of the dust samples collected from different homes by scanning electron microscopy (SEM) which showed images of particles of $2 \mu \mathrm{m}$ to $50 \mu \mathrm{m}$ and fragmented filamentous particles of $50 \mu \mathrm{m}$ to $200 \mu \mathrm{m}$. Microbiological analysis conducted include media culture and microscopic observations where a range of fungal and bacterial colonies were identified with colony forming units in settled dust and air of between $1.02 \times 10^{4}$ to1.18 $\times 10^{5} \mathrm{CFU} \mathrm{g}^{-1}$ and $1.07 \times 10^{4} 1.69 \times$ $10^{5} \mathrm{CFU} \mathrm{m^{-3 }}$ (for fungi)and $7.70 \times 10^{3}$ to1.14 $\times 10^{5} \mathrm{CFU} \mathrm{g}^{-1}, 1.90 \times$ $10^{3}$ to $1.13 \times 10^{5} \mathrm{CFU} \mathrm{m^{-3 }}$ (for bacteria). Metal analysis by ICP-MS (total quant method) of the settled dusts revealed the presence of metal elements in the range of $\mathrm{Al}>\mathrm{Na}>\mathrm{Mg}>\mathrm{Ca}>\mathrm{K}>\mathrm{P}>\mathrm{Si}>\mathrm{Mn}>\mathrm{Ti}$ and indicated the maximum concentration of Lead, Copper, Cadmium, Nickel and Zinc (mg $\mathrm{kg}^{-1}$ ) to bePb-89.7, Cu-68.4, Cd-15.6, Ni-14.9, Zn-1.15.The results also revealed the presence of organic chemical pollutants in varying concentrations in the indoor and outdoor dusts and airborne samples within different homes; eight semi-volatile and volatile organic compounds(SVOCs/VOCs); benzene, hexanal, nonanal, diethyl phthalate (DEP), diisobutylphthalate (DIBP), dibutylphthalate (DBP), and diethylhexylphthalate (DEHP) and limonenewere quantified among the numerous organic chemicals present in the samples analysed based on their frequency of occurrence inthe samples collected, as well as their potential health effects arising from short term and long term exposure as reported in earlier studies. The results suggested that the indoor environments contain considerably more organic chemical pollutants than the outdoors.From the results obtained so far on the chemical, metal, and biological pollutants present as well as the physical characteristics of indoor dusts from Nigerian homes, it can be ascertained that the dusts act as a reservoir of pollutants that can increase peoples' exposure and be a risk to the health of residentsof the community.
\end{abstract}

Index Terms - House dust, indoor air, harmattan haze, dust storm, pollutants.

\section{INTRODUCTION}

People in the Damaturu community of north-eastern Nigeria spend most of their time indoors because of the harsh weather conditions: cold, dry, strong, and dusty wind during winter (Harmattan); thick dust during storms and heavy down pours during the rainy season. Activities like the burning of local and assorted incenses, cooking with wood and other

Manuscript received November 3, 2012; revised December 4, 2012. This work is part of a $\mathrm{PhD}$ research project on Composition of Indoor and Outdoor Dusts and Air in Damaturu, north-eastern Nigeria.

The authors are with the Institute of Environment and Health, Cranfield University, Cranfield, MK43 0AL, Bedfordshire, UK (e-mail: f.mohammed@cranfield.ac.uk,d.crump@cranfield.ac.uk). combusted fuels, burning of mosquito coils and application of aerosols as insect repellents indoors and outdoors also generate particulates and other pollutants such as organic compoundsthat may linger in the air or cling to dust particles. These natural and anthropogenic sources of airborne and deposited dusts may pose risks to the health of the local population. There is however, a general acceptance of the adverse outcomes locally as it is considered as arising from naturalphenomena, thus the need to conduct research on the composition of the dust particles as well as other sources of indoor pollution to improve understanding of the possible risk to health for the Damaturu community.

Dusts are solid particles, ranging in size from below $1 \mu \mathrm{m}$ up to at least $100 \mu \mathrm{m}$, which may be or become airborne, depending on their origin, physical characteristics, and ambient conditions [1]. Dust is found either suspended in the air or settled onto a surface, and originates from a number of sources including soil, abrasion of materials, pesticides, asbestos, pollen, bacteria, shed skin, cigarette smoke and dust mites [2].

Air pollution both indoor and outdoor, is a significant cause of health problems worldwide in both urban and rural environments and is said to be as a result of pollutants which can be classified as(i)- biogenic pollutants which include aerosols of viruses, bacteria, fungal spores and mycelial fragments containing toxic metabolites, pollen, animal dander, dust mite residues and other particles of biological origin[3],[4]; and (ii)-anthropogenic pollutants that emanate from a range of sources which include those that are emitted by the fabric of buildings or as a by-product of the activities that are undertaken within them including combustion of substances for heating or cooking, and for some contaminants infiltration from outside, either through water, air or soil[5], [6].Common house dust is said to contain a mixture of particulateswhichmay form an invisible toxic hazard that scientists have only just begun to study [7].From previous studies, settled dust has been found to be a good surrogate for indoor air pollution and is collected for health monitoring purposes because it represents a direct pathway of human exposure to pollutants through inhalation of re-suspended airborne particulates [8] and ingestion of settled dust that has contaminated food or by hand to mouth contact [9].

\section{MethodOLOGY}

\section{A. Sample Collection}

Settled house dust samples were collected from vacuum cleaner bags in homes, sieved and the $<150 \mu \mathrm{m}$ fractions were used in all the analyses.

Air samples were collected directly on prepared Agar media plates with a Buckard biological monitor. 
Vapours/gases were collected diffusively by exposing Tenax tubes for 14 days (at elevated positions) in living rooms, kitchens, and bedrooms of the homes sampled. Q-Tenax sampling tubes were used to collect air samples actively by attaching a pump (TSI sidepak) to the end of each of the tubes and four liters of air was drawn at the rate of $200 \mathrm{ml}$ per minute for 20 minutes per sampling period during anthropogenic activities; some tubes were kept closed as field blanks.

A novel method of extracting chemical emissions from dust was carried out by heating of the settled house dusts collected from vacuum cleaner bags of homes directly in a micro chamber (Markes International, $\mu-\mathrm{CTE}^{\mathrm{TM}}$ ) and Q-Tenax tubes were used to absorb the chemical emissions released from the dusts.

The initial investigations focussed on samples collected from indoors and outdoors of 5 homes in Damaturu. The settled dusts were collected from living rooms and bedrooms where people tend to spend much of their time, and the outdoor samples were collected from verandas (frontage of homes), while the air samples were collected (diffusively and pumped) indoors during cooking using firewood, kerosene stove and gas cooker use in kitchens; during burning of incense and after insecticide sprays in bedrooms and living rooms. Outdoor air samples were collected (pumped) during electricity generation with petrol and diesel as well as cooking with firewood and during dusty events: Harmattan and sand storm episodes. The airborne sampling using the Burkard biological sampler was done indoors (in bedrooms, living rooms, and kitchens) and outdoors (from verandas).

\section{B. Analyses}

The sizes and shapes of particles in the settled house dust samples were observed with scanning electron microscopy (SEM).For fungal and bacterial cultures approximately $100 \mathrm{mg}$ of each of the samples were weighed and diluted in 9 $\mathrm{ml}$ of water, $200 \mu \mathrm{ml}$ of each of the sample suspensions were smeared on malt extract and nutrient agar respectively. Observed colonies of microbial growth were recorded for both the airborne samples and the dust cultures as colony forming units. The screening for the presence oforganic chemical pollutants (SVOCs/VOCs) was carried out by weighing $1 \mathrm{~g}$ of each of the $<150 \mu \mathrm{m}$ fractions of the settled dust samples and heating in a micro chamber thermal extractor $\left(\mu-\mathrm{CTE}\right.$ )at $120^{\circ} \mathrm{C}$ (maximum temperature of the equipment) for 120 minutes in duplicates, and chemical emissions were collected on Q-Tenax tubes over three periods of 40 minutes each. The airborne samples and blank tubes which accompanied the exposed tubes were also analysed using the same method. All tubes were spiked with $0.5 \mu 1$ of internal standard (d8-toluene) prior to analysis. The tubes were analysed by thermal desorption/gas chromatography/mass spectrometry (TD/GC/MS) using a method developed for the determination of emissions of VOCs from materialsbut with somemodifications.

The metal pollutant analysis was performed whereby $0.5 \mathrm{~g}$ of the sieved dusts were acid extracted using a microwave assisted procedure (in triplicates), and the acid extracts were analyzed for the presence of individual metal analytes byinductively coupled plasma- mass spectrometry(ICP-MS) multi element analysis, and the concentration of the metals obtained were blank corrected.

\section{RESUlTS}

The scanning electron micrographs of the settled dust samples revealed the presence of a variety of particle sizes and shapes, including $\mathrm{PM}_{10}$ and sub- $\mathrm{PM}_{10}$ that are respirable fractions which have the potential of passing through the respiratory tract to potentially cause health problems (Plate $1)$.

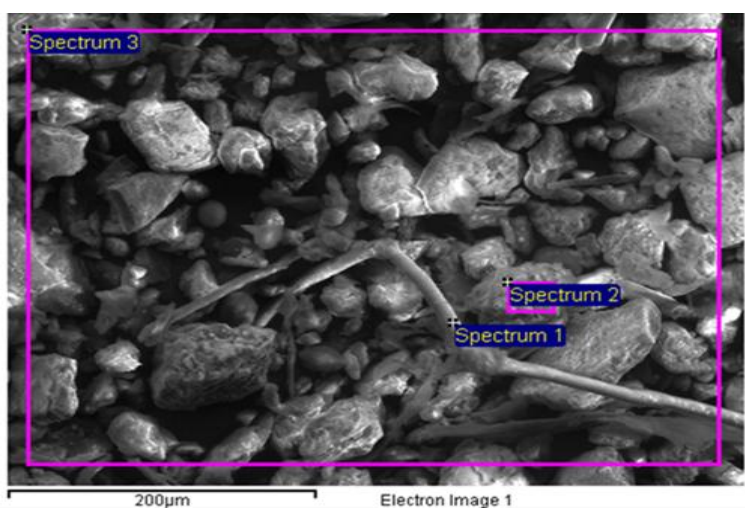

Plate1.SEMimage of settled house dust.

Elemental analysis of selected regions of the sample was undertaken. Rectangular,sharp-edged particles were more conspicuous containing mainly oxygen $(\mathrm{O})$, silicon $(\mathrm{Si})$ and aluminium (Al), and filamentous particles having mainly silicon $(\mathrm{Si})$ and iron $(\mathrm{Fe})$ peaks followed by calcium $(\mathrm{Ca})$, sulphur (S), potassium (K) andaluminium(Al), as in Table I.

TABLEI: ELEMENTAL CONSTITUENTS IN SETTLED DUST (\%).

\begin{tabular}{l|lllllllll}
\hline $\begin{array}{l}\text { Spectru } \\
\mathrm{m}\end{array}$ & $\mathrm{O}$ & $\mathrm{Na}$ & $\mathrm{Al}$ & $\mathrm{Si}$ & $\mathrm{S}$ & $\mathrm{Cl}$ & $\mathrm{K}$ & $\mathrm{Ca}$ & $\mathrm{Fe}$ \\
\hline Spectru & 58.5 & 1.9 & 5.9 & 23.5 & 0.7 & 1.7 & 1.7 & 2.4 & 3.3 \\
$\mathrm{~m} \mathrm{1}$ & 1 & 9 & 0 & 1 & 7 & 5 & 9 & 0 & 8 \\
Spectru & 66.2 & 3.7 & 3.8 & 15.0 & 0.4 & 4.9 & 2.1 & 1.6 & 1.9 \\
$\mathrm{~m} 2$ & 9 & 4 & 0 & 6 & 9 & 4 & 3 & 4 & 3 \\
Spectru & 62.0 & & 4.4 & 25.5 & & 0.8 & 0.5 & 2.3 & 4.2 \\
$\mathrm{~m} 3$ & 1 & & 4 & 1 & & 6 & 0 & 9 & 9 \\
\hline
\end{tabular}

Fungal colonies were physically observed and various species present were identified based on their colours and shapes. The fungal species identified include, Alternaria, Aureobasidum, Aspergillum Niger, Aspergillum flavus, Cladosporium, Fusarium,Penicillium, Pink yeast, White yeast, unidentified white colonies, and unidentified yellow colonies. The bacterial species were observed physically and also under a microscope and were found to be predominantly gram positive which include; Cocci filamentous bacilli and gram negative species-Staphylococcus aureus(Plates II-2a and II-2b).

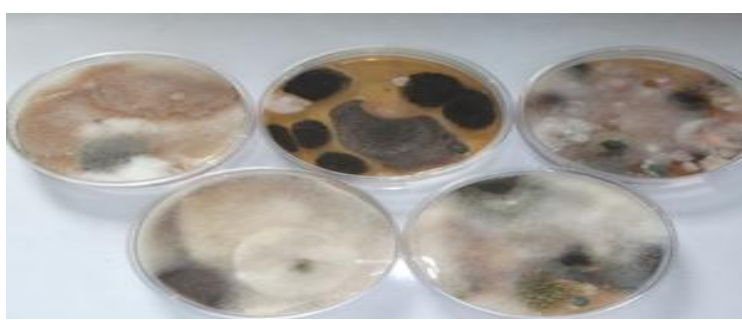




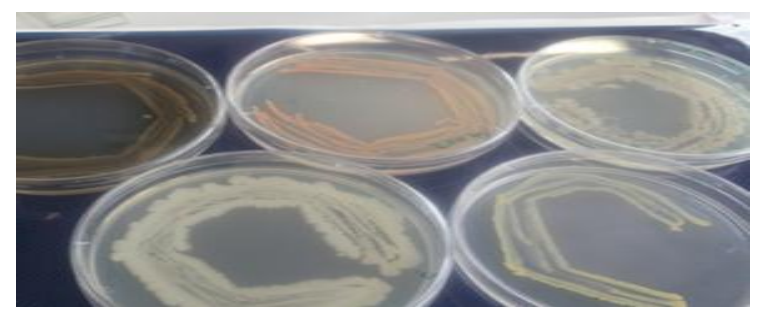

Plate II-2a and II-2b: Fungal and bacterial cultures of settled dust.

TABLE II: AVERAGE, MiNIMUM, AND MAXIMUM FUNGAL AND BACTERIAL COLONIES

\begin{tabular}{|c|c|c|c|c|}
\hline & \multicolumn{2}{|c|}{ Fungal colonies } & \multicolumn{2}{|c|}{ Bacterial colonies } \\
\hline & 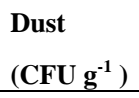 & 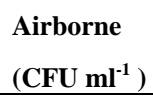 & $\begin{array}{l}\text { Dust } \\
\text { CFU g }{ }^{-1} \text { ) }\end{array}$ & $\begin{array}{l}\text { Airborne } \\
\left(\mathrm{CFU} \mathrm{m} \mathbf{m}^{-1}\right)\end{array}$ \\
\hline Average & $1.89 \times 10^{5}$ & $1.69 \times 10^{5}$ & $1.14 \times 10^{5}$ & $1.13 \times 10^{5}$ \\
\hline $\max$ & $1.18 \times 10^{5}$ & $1.01 \times 10^{5}$ & $6.45 \times 10^{4}$ & $5.96 \times 10^{4}$ \\
\hline $\min$ & $1.02 \times 10^{4}$ & $1.07 \times 10^{4}$ & $7.70 \times 10^{3}$ & $1.90 \times 10^{3}$ \\
\hline
\end{tabular}

The inductively coupled plasma- mass spectrometry (ICP-MS) analysis (total quant method) of the settled dusts revealed the presence of metal elements in the range of $\mathrm{Al}>\mathrm{Na}>\mathrm{Mg}>\mathrm{Ca}>\mathrm{K}>\mathrm{P}>\mathrm{Si}>\mathrm{Mn}>\mathrm{Ti}$. Heavy metals were present with the maximum concentration of lead, copper, cadmium, nickel, and zinc in $\mathrm{mg} \mathrm{kg}^{-1}$ (Pb-8.7, Cu-68.4, Cd-15.6, Ni-14.9, Zn-1.15).The relative standard deviations (RSD) of the mean concentrations were between $14.6 \%$ for $\mathrm{Zn}$ and $82.7 \%$ for $\mathrm{Cu}$. The calculatedgeometric mean (GM), mean, median and maximum values of metals concentrations are shown in Table III.

TABLE IIII: CONCENTRATION (MG KG-1) OF METAL POLLUTANTS IN SETTLED DUSTS.

\begin{tabular}{l|lllllll}
\hline Metals & GM & Mean & Median & Min & Max & SD & RSD\% \\
\hline $\mathbf{Z n}$ & 0.95 & 0.96 & 0.91 & 0.83 & 1.15 & 0.14 & 14.66 \\
$\mathbf{C u}$ & 24.52 & 33.87 & 18.86 & 8.16 & 68.40 & 28.04 & 82.79 \\
$\mathbf{P b}$ & 42.72 & 50.82 & 50.79 & 15.43 & 89.72 & 30.81 & 60.62 \\
$\mathbf{N i}$ & 8.92 & 9.53 & 10.41 & 5.75 & 14.99 & 3.82 & 40.08 \\
$\mathbf{C d}$ & 6.19 & 7.11 & 5.15 & 4.22 & 15.66 & 4.85 & 68.15
\end{tabular}

$\mathrm{Zn}$ had the minimum concentration in all the samples with least $\mathrm{RSD}$ percentage followed by $\mathrm{Ni}$ with $\mathrm{RSD}<50 \%$. However, $\mathrm{Pb}, \mathrm{Cu}$, and $\mathrm{Cd}$ have $\mathrm{RSD}$ above $50 \%$ indicating differences in the respective metals among the different houses sampled.

The TD/GC/MS analyses revealed the presence of many organic chemical compounds covering a broad volatility range and varying concentrations in all the dust and air samples analysed as shown by examples of the TD/GC/MS chromatograms obtained (Fig. 1). The more volatile compounds elute with a shorter retention time (x-axis).

Seven chemicals of interest were quantified $\left(\mathrm{ng} \mathrm{g}^{-1}\right)$ from the settled dust sample data and limonene was additionally quantified in the airborne samples. This selection was done based on the health hazard of the chemicals as reported in other studies (mostly found as irritants and causes of allergic diseases), their frequency of occurrence in the various samples, the suitability of the analytical method and the quantification limit of the analytical equipment used. The chemicals are benzene, hexanal, nonanal, diethyl phthalate (DEP), diisobutylphthalate (DIBP), dibutylphthalate (DBP), and diethylhexylphthalate (DEHP) (Fig. 2).

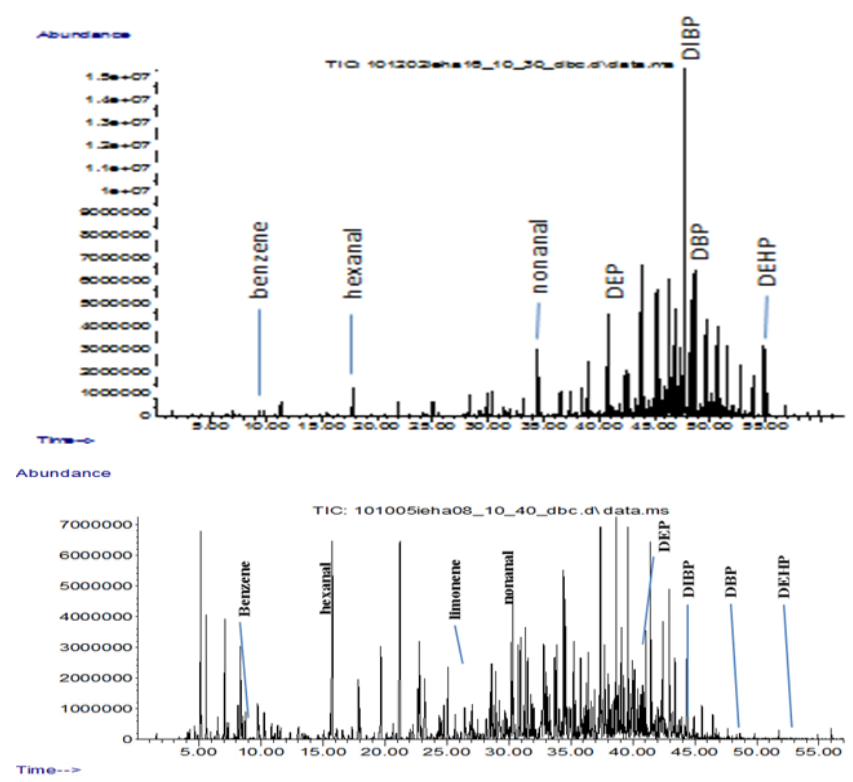

Fig. 1. Chromatograms indicating the presence of chemical pollutants in (a) housedust and (b) air samples.

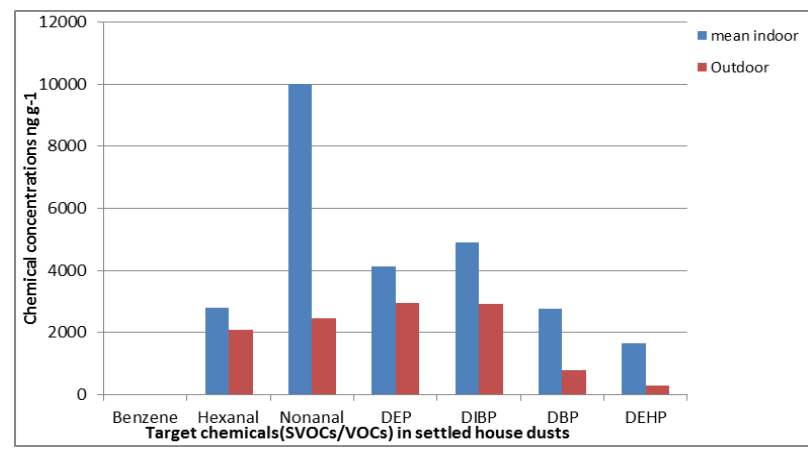

Fig. 2. Mean chemical concentrations $\mathrm{ng} \mathrm{g}^{-1}$ in settled dusts released by heating to $120^{\circ} \mathrm{C}$

The organic chemical concentrations released by heating ranged from a mean $36 \mathrm{ng} \mathrm{g}^{-1}$ for benzene having the least concentrationto $10000 \mathrm{ng} \mathrm{g}^{-1}$ of dust for nonanal with the highest concentration in the indoor samples. Generally the indoor samples had more chemical emissions than the outdoor veranda samples as shown in Fig. 2.Surface soil (predominantly sand) samples were collected at a distance from the township buildings by using the same vacuum cleaner that was used in the sample collection and analysed to check any possible contamination of the samples and the results analysed (in duplicates) did not show the presence of any detectablechemicals.

During active air sampling, DEP had the highest concentration of $1630 \mathrm{ng} \mathrm{l}^{-1}$ (concurrent with use of a petrol driven electricity generator) with most of the quantified chemicals having concentrations of $<1$ in air sampled during Harmattan haze and sand storm.In the diffusive samples nonanal had higherconcentrations of $366 \mathrm{ng}^{-1}$ followed by hexanal 276ng $\mathrm{l}^{-1}$ and limonene 136ng $\mathrm{l}^{-1}$ in samples that were collected from living rooms during the Harmattan period. 
Total volatile organic compound concentrations (TVOCs) which are the sum of all VOCs found with volatilities between those of $n$-hexane and n-hexadecane were quantified using the calibration factor for toluene in the air samples. The highest TVOC value was $18,060 \mathrm{ng}^{-1}$ in a sample collected during the use of adiesel generator, followed by petrol generator and kerosene stove cooking, while a Harmattan haze sample had a TVOC concentration of $152 \mathrm{ng} \mathrm{l}^{-1}$ whichis an indication that human activities generate more chemical pollutants than the natural weather events.

\section{Discussions}

House dusthas been used as a medium for assessing human exposures to a constellation of indoor contaminants including radionuclides[10], persistent organic pollutants [11], [12], metals[13], [14], [15], [16], and allergens[17],[18]. From the results obtained so far on the chemical and biological pollutants present as well as the physical characteristics of dusts from Nigerian homes, it can be ascertained that dust could be an important cause of health effects to the communities.

The SEM images were shown to constitute particles of $2 \mu \mathrm{m}$ to $50 \mu \mathrm{min}$ size (respirable) fractions thus, can potentially cause health hazards as described by[19], [20],[21].

The colony counts on both bacterial and fungal plates indicated the presence of various microbial entities inthe settled dusts as well as the airborne samples which ranged from a few hundred to several thousand colony forming units. The spores of fungal and bacterial species were present in all samples at varying concentrations. The microbial flora identified are similar to those reported by other researchers as indoor air pollutants that cause short term respiratory and inflammatory health effects, which may potentially lead to chronic, long term health impacts[22], [23].

The ICP-MS analysis revealed the presence of several metal elements in the indoor dusts. The heavy metals were found to be present in all the samples analysed and in varying concentrations; other researchers have reported similar results [7], [13], [ 24], [25] and suggesting potential health hazards related to elevated trace metal elements levels in house dusts[26].

The TD/GC/MS results showed numerous organic compounds collected on the adsorbent tubes, which conforms with studies that reported the presence of VOCs and SVOCs in indoor settled dusts and air [27], [28],[29],[30],[31], [32].The dust data shows that the indoor environment contains considerably more organic chemical pollutants than the outdoor[33],[34].Burning of fossil fuels (petrol, kerosene, and diesel) showed higher benzene and aldehydes emissions than the normal indoor activities and these could infiltratefrom outdoors e.g. use of generators, due to strong Harmattan wind and the chemicals may accumulate and persist indoors.

Studies are on-going on the determination of metal contaminants in the settled dust samples as well as SVOCs/VOCs analysis in 52 settled dust samples collected from indoors and outdoors of homes in Damaturu, Nigeria based on the type of buildings and occupancy.
Studies are also being undertaken in order to assess the health risk of the dusts by comparative study on the types and levels of pollutants determined with those obtained in other studies. The exposure assessment will also be carried out by consideration of the exposure limits ascertained by the regulatory agencies such as EU, WHO, US-EPA etc. and compared with the levels analysed in the dust samples.

\section{REFERENCES}

[1] World Health Organization, "Hazard Prevention and control in the work environment: Airborne dust," Prevention and Control Exchange (PACE). Geneva: WHO, Department of Protection of the Human Environment, Occupational Environmental Health, 1999.

[2] L. Morawska and T. Salthammer, Indoor environment, Wiley-VCH, pp. 23-39, 2006

[3] S. Litten, B. Fowler, and D. Luszniak, "Identification of a novel PCB source through analysis of 209 PCB congeners by US EPA modified method 1668," Chemosphere, vol. 46, no. 9, pp. 1457-1459, 2002.

[4] P. J. Landrigan, P. J. Lioy, G.Thurston, G. Berkowitz, L. Chen, S. N. Chillrud, S. H. Gavett, P. G. Georgopoulos, A. S. Geyh, and S. Levin, "Health and environmental consequences of the world trade center disaster," Environmental health perspectives,vol. 112, no. 6, pp. 731, 2004.

[5] A. P. Jon, "Indoor air quality and health," Atmospheric Environment, vol. 33, no. 28, pp. 4535-4564, 1999.

[6] N. C. Jones, C. A. Thornton, D. Mark, and R. M. Harrison, "Indoor/outdoor relationships of particulate matter in domestic homes with roadside, urban and rural locations," Atmospheric Environment, vol. 34 , no. 16 , pp. 2603-2612, 2000.

[7] I. F. Al-Momani, "Trace elements in street and household dusts in Amman, Jordan," Soil and Sediment Contamination, vol. 16, no. 5, pp. 485-496, 2007.

[8] L. Morawska, "Indoor particles, combustion products and fibres," Air Pollution, pp. 117-147, 2004.

[9] T. Schripp, M. Wensing, E. Uhde, T. Salthammer, C. He, and L. Morawska, "Evaluation of ultrafine particle emissions from laser printers using emission test chambers," Environmental Science and Technology, vol. 42, no. 12, pp. 4338-4343, 2008.

[10] L. Mølhave, S. K. Kjærgaard, and J. Attermann, "Sensory and other neurogenic effects of exposures to airborne office dust," Atmospheric Environment, vol. 34, no. 28, pp. 4755-4766, 2000.

[11] N. Ali, N. V. D. Eede, A. C. Dirtu, H. Neels, and A. Covaci, "Assessment of human exposure to indoor organic contaminants via dust ingestion in Pakistan," Indoor air, pp. 2-6, 2012.

[12] F. Mercier, P. Glorennec, O. Thomas, and B. L.Bot, "Organic contamination of settled house dust, a review for exposure assessment purposes," Environmental Science and Technology, vol. 45, no. 16, pp. 6716-6727, 2011.

[13] M. A. A. Rajhi, M. R. D. Seaward, and A. S. A. Aamer, "Metal levels in indoor and outdoor dust in Riyadh, Saudi Arabia," Environment international, vol. 22, no. 3, pp. 315-324, 1996.

[14] E. U. Etim and P. C. Onianwa, "Lead contamination of soil in the vicinity of a military shooting range in Ibadan, Nigeria," Toxicological and Environmental Chemistry, vol. 94, no. 5, pp. 895-905, 2012.

[15] S. W. Kim, S. C. Yoon, A. Jefferson, J. A. Ogren, E. G. Dutton, J. G. Won, Y. S. Ghim, L. B. I ee, and J. S. Han, "Aerosol optical, chemical and physical properties at Gosan, Korea during Asian dust and pollution episodes in 2001," Atmospheric Environment, vol. 39, no. 1 , pp. 39-50, 2005.

[16] M. Gomez, M. Gomez, and M. Palacios, "ICP-MS determination of Pt, $\mathrm{Pd}$ and $\mathrm{Rh}$ in airborne and road dust after telluriumcoprecipitation," Journal of Analytical Atomic Spectrometry, vol. 18, no. 1, pp. 80-83, 2003.

[17] M. Daisey, W. J. Angell, and M. G. Apte, "Indoor air quality, ventilation and health symptoms in schools: an analysis of existing information," Indoor Air, vol. 13, no. 1, pp. 53-64, 2003.

[18] D. S. Bijkerk, G. Doekes, M. Boeve, J. Douwes, J. Riedler, E. Üblagger, E. V. Mutius, M. Benz, G. Pershagen, and M. Wickman, "Exposure to microbial components and allergens in population studies: A comparison of two house dust collection methods applied by participants and fieldworkers," Indoor Air, vol. 16, no. 6, pp. 414-425, 2006.

[19] C. Horwell, R. S. J. Sparks, T. Brewer, E. Llewellin, and B. Williamson, "Characterization of respirable volcanic ash from the Soufrière Hills volcano, Montserrat, with implications for human health hazards", Bulletin of Volcanology, vol. 65, no. 5, pp. 346-362, 2003. 
[20] V. Shilton, P. Giess, D. Mitchell, and C. Williams, "The characterisation of settled dust by scanning electron microscopy and energy dispersive x-ray analysis," Water, Air, and Soil Pollution: Focus, vol. 2, no. 5, pp. 237-246, 2002.

[21] M. C. Todd, R. Washington, J. V. Martins, O. Dubovik, G. Lizcano, S M. Bainayel, and S. Engelstaedter, "Mineral dust emission from the Bodélé Depression, northern Chad, during BoDEx 2005," Journal of Geophysical Research, vol. 112, no. D6, pp. D06207, 2007.

[22] H. Rintala, M. Pitkäranta, M. Toivola, L. Paulin, and A. Nevalainen, "Diversity and seasonal dynamics of bacterial community in indoor environment," BMC Microbiology, vol. 8, no. 1, pp. 56, 2008.

[23] O. Maggi, A. M. Persiani, F. Gallo, P. Valenti, G. Pasquariello, M. C. Sclocchi, and M. Scorrano, "Airborne fungal spores in dust present in archives: Proposal for a detection method, new for archival materials," Aerobiologia, vol. 16, no. 3, pp. 429-434, 2000.

[24] F. M. Darus, R. A. Nasir, S. M. Sumari, Z. S. Ismail, and N. A. Omar, "Nursery schools: Characterization of heavy metal content in indoor dust," 2011.

[25] M. N. Rashed, "Total and extractable heavy metals in indoor, outdoor and street dust from Aswan City, Egypt," CLEAN-Soil, Air, Water, vol. 36 , no. $10-11$, pp. 850-857, 2008

[26] R. M. Maertens, J. Bailey, and P. A. White, "The mutagenic hazards of settled house dust: a review," Mutation Research/Reviews in Mutation Research, vol. 567, no. 2, pp. 401-425, 2004.
[27] P. Wolkoff and C. Wilkins, "Indoor VOCs from household floor dust: comparison of headspace with desorbed VOCs; Method for VOC release determination," Indoor Air, vol. 4, no. 4, pp. 248-254, 2004

[28] P. Wolkoff, P. Clausen,B. Jensen, G. Nielsen, and C. Wilkins, "Are we measuring the relevant indoor pollutants?" Indoor Air, vol. 7, no. 2, pp. 92-106, 2004.

[29] C. J. Weschler, "Chemical reactions among indoor pollutants: what we've learned in the new millennium," Indoor Air, vol. 14, no. 7, pp 184-194, 2004

[30] C. Wilkins, P. Wolkoff, F. Gyntelberg, P. Skov, and O. Valbjørn, "Characterization of office Dust by VOCs and TVOC release-identification of potential irritant VOCs by partial least squares analysis," Indoor Air, vol. 3, no. 4, pp. 283-290, 1993.

[31] A. Hirvonen, P. Pasanen, J. Tarhanen, and J. Ruuskanen, "Thermal desorption of organic compounds associated with settled household dust, "Indoor Air, vol. 4, no. 4, pp. 255-264, 2004.

[32] V. B. D. Crump, "Analysis of organic chemicals in household dust," Proceedings of Indoor Air, Copenhagen, pp. 524, 2008.

[33] Y. Guo and K. Kannan, "Comparative assessment of human exposure to phthalate esters from house dust in China and the United States," Environmental Science and Technology, 2011, vol. 45, no. 8, pp. 3788-3794.

[34] S. K. Brown, "Occurrence of volatile organic compounds in indoor air," Organic Indoor Air Pollutants. Occurrence-Measurement-Evaluation, pp. 170-184, 2007 